\title{
Back Massage Therapy to Reduce Low Back Pain in Pregnancy
}

\author{
$1^{\text {st }}$ Indah Puspitasari \\ Midwifery Departement \\ Health Faculty \\ Universitas Muhammadiyah Kudus \\ Indonesia \\ *indahpuspitasari@umkudus.ac.id
}

\author{
$2^{\text {nd }}$ Irawati Indrianingrum \\ Midwifery Departement \\ Health Faculty \\ Universitas Muhammadiyah Kudus \\ Indonesia
}

\begin{abstract}
Pregnancy is a unique natural condition experienced by women. In pregnant women, an adjustment process occurs that can cause physiological changes, which cause discomfort in pregnant women. In most pregnant women report almost 50\% - 80\% feel discomfort back pain experienced by mothers during pregnancy. Pregnancy with low back pain (LBP) is a common complaint that occurs in pregnant women. This can potentially affect the quality of their lives which will have a negative impact. Factors that influence LBP include mechanical, hormonal and other factors. Massage therapy is a non-pharmacological method that provides pressure by the hands on soft tissue, usually on muscles, tendons or ligaments, without causing a shift or change in joint position to reduce pain, produce relaxation, and improve circulation. By paying attention to the things mentioned above, researchers are interested in conducting a study of the effect of back massage therapy on decreasing low back pain in pregnant women. Method: This research is a type of experimental research, nonequivalent control group design and research approaches using quasi-experimental or quasi-experimental research. The population in this study were all pregnant women in the area of Kudus Gribig Health Center. Samples amounted to AugustSeptember 2018 of 30 pregnant women. The sampling technique uses consecutive sampling that meets the inclusion and exclusion criteria. The inclusion criteria were trimester 3 (28-32 weeks) pregnant women, primiparous and multiparous, experiencing back pain, and willing to be the subject of research. The results showed that there were significant differences before and after back massage was given to decrease lower back pain in pregnant women. Conclusion: the application of back massage therapy has proven to be effective in reducing the discomfort of low back pain experienced by pregnant women. It is important for midwives to support pregnant women in antenatal care, especially in utilizing non-pharmacological methods as an effective method for reducing discomfort during pregnancy.
\end{abstract}

Keywords-Massage, Therapy, Reduce Low, Back Pain, pregnancy

\section{INTRODUCTION}

Pregnancy is a unique natural condition experienced by women. In pregnant women, an adjustment process occurs that can cause physiological changes, which cause discomfort in pregnant women.[1] During pregnancy several maternal body systems experience changes that result from fetal development that occurs. These changes are the basis for the emergence of discomfort that occurs in most pregnant women. This will cause changes in the mother's body, which causes discomfort due to changes in the mother's body such as changes in external genetal organs, internal genetals and breasts, increased hormones namely the hormones somatomammotropin, estrogen and progesterone, maternal psychology such as attention and affection for her pregnancy and fetal development over time. From these changes, eventually the mother will experience a period that causes the mother to feel uncomfortable and disturbed. Generally this physiological state occurs even without the need to use certain medications. But sometimes if not handled properly this discomfort will turn into a pathological state that can interfere with maternal activity, can even endanger the pregnancy of the mother.[2]

In most pregnant women report almost 50\% - 80\% feel discomfort during pregnancy. Among the discomforts due to back pain experienced by mothers during pregnancy. [3] A number of studies on back pain related to pregnancy are around $25 \%$ to $90 \%$, most studies estimate that $50 \%$ of pregnant women will suffer from back pain. One third of them will suffer severe pain, which will reduce their quality of life. $80 \%$ of pregnant women who suffer from back pain while pregnant say that it affects their daily routine and $10 \%$ of them report that they cannot work.[3] About $80 \%$ of women will experience back pain at some point during pregnancy. Most back pain during pregnancy results from changes in the backbone muscles that are as much as $70 \%$. Without strong back muscles, injuries to the ligamental will get worse so that posture worsens, the rest or $30 \%$ of back pain during pregnancy may be due to irregularities in the condition of the spine that occurred before.[4]

Discomfort of back pain in pregnancy may be expected by most pregnant women, but what they want if this is experienced over and over is the knowledge gained during antenatal care about how to cope or reduce the pain or discomfort.[2]

Pregnancy with low back pain (LBP) is a common complaint that occurs in pregnant women. This can potentially affect the quality of their lives which will have a negative impact. Factors that influence LBP include mechanical, hormonal and other factors.[3] During pregnancy along with the enlargement of the uterus, the center of gravity will move towards the front so that pregnant women must adjust their position, where pregnant women must depend on muscle strength, weight gain, joint relaxation, fatigue and posture before pregnancy. Improper posture will force additional stretching and fatigue in the body, especially in the spine so that it will cause pain or pain in the back of pregnant women.[5] 
This is in line with the theory that the process of pregnancy will cause various changes in the entire body system. The impact of changes in the musculoskeletal system often causes pregnant women to feel pain in the lower back region. The enlargement of the uterus affects the center of gravity, stretches out and weakens the abdominal muscles, changes posture and puts pressure on the back. This is what causes back pain, besides being overweight will certainly affect the muscles to work more so that it causes stress on the joints.[6, 7]

Lower back pain in pregnant women is the most frequently reported problem in pregnancy. Lower back pain experienced by pregnant women will reach its peak in the 24th to 28th week, just before the abdominal growth reaches its maximum point. During this time pregnant women consider that complaints of back pain is a natural thing that occurs during pregnancy. So the efforts that have been made so far to reduce complaints of low back pain are just resting. Usually to reduce back pain, pregnant women only rest or lie alone because the average thought the pain will decrease by itself. Then at the time of control at the doctor or midwife they rarely complain of back pain because it is considered normal for pregnant women. If when you are back pain, it will inhibit the activity of pregnant women.[7]

According to the results of research various complementary techniques that can be applied to the treatment of low back pain in pregnancy that have been developed include massage $(61.4 \%)$, relaxation $(42.6 \%)$, chiropractic $(36.6 \%)$, acupuncture $(44,6 \%)$, yoga $(40.6 \%)$ and acupressure.[8] One non-pharmacological method that can reduce pain is massage, which is also a nonpharmacological method that gives pressure to the hands on soft tissue, usually on muscles, tendons or ligaments, without causing a shift or change in joint position to reduce pain, produce relaxation, and increase circulation.[7]

By paying attention to the things mentioned above, researchers are interested in conducting a study of the effect of back massage therapy on decreasing low back pain in pregnant women.

\section{METHODS}

This research is a type of experimental research. Using a non equivalent control group design and research approach using quasi-experimental or quasi-experimental. The population in this study were all pregnant women in the area of Kudus Gribig Health Center. Samples amounted to AugustSeptember 2018 of 30 pregnant women. The sampling technique in this study uses consecutive sampling that meets the inclusion and exclusion criteria.

The inclusion criteria in this study were pregnant women trimester 3 (28-32 weeks), primiparous and multiparous, experiencing back pain, and willing to be the subject of research. Exclusion criteria were pregnant women with complications, comorbidities, gameli diagnoses, and women who moved places. The data collected comes from primary data and secondary data. Data collection was started by collecting secondary data, namely data of third trimester pregnant women who experienced complaints and fulfilled the inclusion and exclusion criteria in the working area of the Gribig Community Health Center in Kudus Regency. After collecting secondary data, the researchers then collected primary data for both dependent and independent variables. Previously, pregnant women as respondents were asked to be willing to play a role in this study. If you are willing, then you sign the informed consent form. Furthermore, pregnant women were measured the level of back pain felt using a visual analogue scale (Visual Analog Scale, VAS) which is a horizontal line with a range of $0-10$. as a pre test. Then back massage is performed on pregnant women by the husband or researcher. The technique of massage on the back in question is to give a gentle and unstressed stroke with gentle rubbing with both palms and fingers on the back of the maternal cervical high 7 outward towards the side of the rib cage with a duration of 30 minutes with a frequency of 40 times rubbing / minute, but try the tip of the finger does not escape the surface of the skin.[9-11] This massage therapy is carried out by the mother at home for four weeks (28 days).

After that, the researchers then gave a post-test to measure the severity of back pain felt by the mother after back massage therapy. The instrument used to collect data from the independent and dependent variables was a questionnaire with several questions regarding characteristics (age, education, occupation, and parity) and low back pain that the mother felt. Then the data is collected for further data processing and data presentation. Data processing uses the Wilcoxon Test to determine the effect of back massage therapy on reducing low back pain in pregnant women.

\section{FINDING AND DISCUSSION}

The results of the study include data normality tests, and differences in lower back pain in pregnant women before and after back massage therapy.

TABLE I. NORMALITY TEST BASED ON THE PAIN VARIABLE

\begin{tabular}{|l|c|c|c|}
\hline \multicolumn{1}{|c|}{ Variable } & $\begin{array}{c}\text { Respondent } \\
\text { N=30 }\end{array}$ & \% & \multirow{2}{*}{0.000} \\
\cline { 1 - 3 } Pain_pre & & & \\
\cline { 1 - 3 } Mild pain & 17 & 56.7 & \\
\hline Moderate pain & 7 & 23.3 & \multirow{2}{*}{0.000} \\
\cline { 1 - 3 } Severe pain & 6 & 20 & \\
\cline { 1 - 3 } Pain_post & & 13.3 & \\
\cline { 1 - 3 } No Pain & 4 & 66.7 & \\
\cline { 1 - 2 } Mild pain & 20 & 20 & \\
\cline { 1 - 2 } Moderate pain & 6 & *Shapiro-Wilk
\end{tabular}

Table1 Shows that the In the normality test, the significance value obtained for the two data groups is $\mathrm{p}<0.05$, which means the distribution of the two data is not normal, so the paired group difference test uses the Wilcoxon Test

TABLE 2. DIFFERENCE IN DECREASE IN LOW BACK PAIN IN
PREGNANT WOMEN BEFORE AND AFTER GIVEN BACK
\begin{tabular}{|l|c|c|}
\hline Variable & $\mathrm{n}$ & $\mathrm{P}^{*}$ \\
\hline Pain_pre & 30 & 0,002 \\
\hline Pain_post & 30 & \\
\hline
\end{tabular}

Table2 Shows that the Based on the results of data analysis, there are differences in lower back pain in pregnant women between before and after given back massage therapy, with a value ( $\mathrm{p}<0.05)$. So that Ho is accepted and Ha is rejected. So, the results showed that there were significant differences 
before and after back massage was given to decrease lower back pain in pregnant women.

\section{DISCUSSION}

During pregnancy, the posture of the mother's body will change naturally. The hormones produced during pregnancy cause the ligaments that support the joint to relax. This makes the joints experience more movement and more risk of injury. During pregnancy, weight will lean forward or heavier on the front, thereby shifting the center of gravity. The position of the joints and muscles, especially on the pelvis and lower back, so that it can make pregnant women become less stable and lose balance, especially in late pregnancy, this can cause pain in the back.[21]

Pain is an uncomfortable feeling that is very subjective and only the person who experiences it can explain and evaluate the feeling. The level of pain is said to be severe pain if the pregnant woman subjectively says severe pain and objectively the client cannot follow orders but still responds to actions, can indicate the location of pain, cannot be overcome with deep breathing techniques and distractions properly and does not affect activity. If back pain is not treated immediately, it can lead to long-term back pain, increasing the tendency of postpartum back pain and chronic back pain that will be more difficult to treat or cure.[22] Back pain (LBP) is a difficult condition to prevent, but it is important to inform the mother about methods that mothers can take to overcome and reduce low back pain during pregnancy including how to maintain body posture in daily activities, how to lift weights, sleeping position and application back massage therapy that is proven effective in reducing back pain.[2]

Back massage therapy, a non-pharmalogical method that is without using drugs, is safer, simpler, does not require many tools, is easy to do and does not cause adverse effects and refers to the care of dear mothers. This massage aims to improve blood circulation, put pressure on, and warm the abdominal muscles and increase physical and mental relaxation.[10]

Massage on the back stimulates certain points along the spinal cord meridians that are transmitted through large nerve fibers to the reticular formation, that thealamus and limbic system of the body will release endorphins. Endorphins are neurotransmitters or neuromodulators that inhibit the delivery of pain stimuli by attaching opiate receptors to nerves and spinal cord so that they can block pain messages to a higher center and can reduce pain sensations.[11]

This back massage therapy can be done both by health workers, the patient's family, and the patient himself. Massage on the back stimulates the receptors that make the mother more comfortable due to muscle relaxation.

Back massage can relax a number of muscles in the back area that will stimulate the limbic system in the hypothalamus to release corticotropin releasing factor (CRF). The substance will stimulate the pituitary to increase endorphin secretion and pro opioid melano cortin (POMC) which will increase the production of encephalines by the adrenal medulla so that it will affect mood and give a relaxed feeling.[23]

Relaxation techniques will stimulate endorphins secretion in the brain. The statement was supported by Newberg and Waldman (2013) who found that feeling comfortable, both physically and psychologically, is a response from the expenditure of endorphins. Based on these two findings, back massage can stimulate an increase in endorphins. Relaxation will trigger the release of endorphins. The hormone is in the form of polypeptides which contain 30 units of amino acids that bind to opiate receptors in the brain. This hormone acts like morphine, even said to be 200 times more effective than morphine. Endorphins can cause feelings of euphoria, happy, comfortable, create calm and improve one's mood to make someone relax. Relaxation will trigger the limbic system and trigger the hypothalamus to secrete endorphins. Under these conditions, the concentration of endorphins in the brain will increase. Increased endorphins in the brain will create a feeling of physical relaxation. With increasing endorphins, cortisol secretion will be suppressed so that the mother will feel a psychological sensation of relaxation. Increased endorphins after back massage will cause vasodilation of blood vessels which has implications for improving circulation where oxygen and energy supply is improved. In addition, feeling relaxed will reduce the metabolic rate and reduce energy requirements. Increased endorphins will be followed by simultaneous suppression of cortisol. With the decrease in cortisol, it will reduce psychological problems such as depression and anxiety. Back massage is an intervention that can affect the physical and psychological aspects of the mother.[23, 24].

\section{CONCLUSION}

Based on the results of the study, it was found that the application of back massage therapy has been proven effective in reducing the discomfort of low back pain experienced by pregnant women. It is important for midwives to support pregnant women in antenatal care, especially in utilizing non-pharmacological methods as an effective method to reduce discomfort during pregnancy. Apart from being safer, not requiring many tools, easy to do and not causing side effects and referring to maternal care, it also aims to increase the mother's physical and psychological relaxation.

\section{ACKNOWLEDGMENT}

We thank to the participants, Rector of Muhammadiyah University of Kudus, the department of research and community service and those who have helped this research: To the Gribig Community Health Center, Gebog Subdistrict, Kudus Regency.

\section{REFERENCES}

[1] B. Irianti, E. M. Halida, F. Duhita, F. Prabanda, N. Yulita, S Hartiningtyaswati, et al., Asuhan Kehamilan Berbasis Bukti. Jakarta: Sagung Seto, 2014.

[2] E. I. Syafriani, "Penatalaksanaan Nyeri Punggung (Low Back Pain) Pada Ibu Hamil," Proceeding Book: Simposium dan Workshop 
Nasional Pengembangan Pendidikan dan Pelayanan Kebidanan Indonesia, vol. 2, pp. 5-8, 13 Juni 20152015

[3] Katonis, Kampouroglou, Aggelopoulos, Kakavelakis, Lykoudis, Makrigiannakis, et al., "Pregnancy-related low back pain," Hippokratia, vol. 15, pp. 205-210, 2011.

[4] A. S. K. Wardani, "Penerapan Effleurage Massage untuk Mengurangi Nyeri Punggung Bawah Ibu Hamil Trimester III di BPM Yuspoeni Kecamatan Klirong Kabupaten Kebumen," S. T. I. K. M. Gombong, Ed., ed. Gombong, 2017.

[5] D. N. Lilis, "Pengaruh Senam Hamil Terhadap Nyeri Punggung Bawah pada Ibu Hamil Triemster III," pp. 41-45, 2019.

[6] K. RI, "Panduan Teknis Latihan Fisik selama Kehamilan dan Nifas," K. RI, Ed., ed. Jakarta: Kemenkes RI, 2010.

[7] A. Alloya, "Beda Pengaruh antara Senam Hamil dengan Kompres Hangat dan Massage Terhadap Penurunan Nyeri Punggung Bawah pada Ibu Hamil Trimester III," Program Studi S1 Fisioterapi Fakultas Ilmu Kesehatan Universitas Muhammadiyah Surakarta, Surakarta, 2016.

[8] Niken Tri Sukeksi, Gita Kostania, and E. Suryani, "Pengaruh Teknik Akupressure terhadap Nyeri Punggung pada Ibu Hamil di Wilayah Puskesmas Jogonalan I Klaten " Jurnal Kebidanan dan Kesehatan Tradisional, vol. 3, pp. 1-7, Maret 20182018

[9] R. Pastuty, Buku Saku Asuhan Kebidanan Ibu Bersalin. Jakarta: EGC, 2010 .

[10] Indah Puspitasari and D. Astuti, "Tehnik Massage Punggung untuk Mengurangi Nyeri Persalinan Kala I," Jurnal Ilmu Keperawatan dan Kebidanan, vol. 8, pp. 100-106, 2017.

[11] Yeni Aryani, Masrul, and L. Evareny., "Pengaruh Masase pada Punggung terhadap Intensitas Nyeri Kala I Fase Laten Persalinan Normal melalui Peningkatan Kadar Endorfin," jurnal Kesehatan Andalas, vol. 4, pp. 70-78, 2015.

[12] C. T. Purnami and Mas'udah, "Hubungan karakteristik ibu keluarga miskin dengan pemilihan tempat pemeriksa kehamilan $\mathrm{d}$ Kecamatan Sulang Kabupaten Rembang Tahun2006," Jurnal Promosi Kesehatan Indonesia, vol. 2, pp. 47-52, Januari 20072007.

[13] Nasriyah, "Hubungan faktor sosiodemografi dan kunjungan antenatal care ibu pekerja buruh pabrik dengan hasil luaran bayi,"
Program Studi S2 Kebidanan, Universitas Padjadjaran Bandung, Bandung, 2013.

[14] C. Sistiarani, E. Gamelia, and D. U. P. Sari, "Fungsi pemanfaatan buku KIA terhadap pengetahuan kesehatan ibu dan anak pada ibu," Jurnal Kesehatan Masyarakat Nasional, vol. 8, 2014.

[15] Y. Dharmawan, "Hubungan karakteristik terhadap pengetahuan dan sikap kader kesehatan tentang pentingnya data di buku KIA," Pena Jurnal Ilmu Pengetahuan dan Teknologi, 2015.

[16] A. A. A. Ali, M. M. Osman, A. O. Abbaker, and I. Adam, "Use of antenatal care services in Kassala, eastern Sudan," BMC Pregnancy and Childbirth, vol. 10, p. 67, 2010

[17] M. H. Mustafa and A. M. Mukhtar, "Factors associated with antenatal and delivery care in Sudan: analysis of the 2010 Sudan household survey," BMC Health Services Research, vol. 15, p. 452, 2015.

[18] Priyoto, Teori sikap dan perilaku dalam kesehatan Yogyakarta: Nuha Medika, 2014.

[19] V. Khanal, J. Lourenca, S. R. Mishra, R. Karkee, and A. H. Lee, "Under-utilization of antenatal care services in Timor-Leste: results from Demographic and Health Survey 2009-2010," BMC Pregnancy and Childbirth, vol. 15, p. 211, 2015.

[20] T. W. Sari, F. Agushybana, and Y. Dharmawan, "Analisis spasial pemilihan tempat pertolongan persalinan di Kelurahan Sendangmulyo Semarang Tahun 2010 " Jurnal Kesehatan Reproduksi, vol. 1, pp. 113-124, Agustus 20112011.

[21] N. H. Jalilah, "Proceeding Book: Yoga dan Philates selama Kehamilan," in Workshop Nasional Pengembangan Pendidikan dan Pelayanan Kebidanan Indonesia, Bandung, 2014.

[22] Ratih Indah Kartikasari and A. Nuryanti., "Pengaruh Endhorphin Massage terhadap Penurunan Intensitas Nyeri Punggung Ibu Hamil," in RAKERNAS AIPKEMA Temu Ilmiah Hasil Penelitian dan Pengabdian Masyarakat, Yogyakarta, 2016, pp. 297-304.

[23] Bambang Aditya Nugraha, Sari Fatimah, and T. Kurniawan., "Pengaruh Pijat Punggung terhadap Skor Kelelahan Pasien Gagal Jantung," Jurnal Keperawatan Padjadjaran, vol. 5, pp. 65-72, 1 April 20172017.

[24] Newberg and Warldman, "World can change your brain," American Journal of Clinical Hypnosis, vol. 56, 2013. 